\title{
MEGLÉVő AUTOMATIZÁLT ÉPÜLETEK INTEGRÁCIÓJA
}

\section{CONSOLIDATING THE CONTROL OF ALREADY AUTOMATED HOMES}

\author{
Dombi Kristóf Barnabás ${ }^{1}$, Tóth János ${ }^{2}$ \\ Debreceni Egyetem, Müszaki Kar, Mechatronikai Tanszék, 4028 Magyarország, \\ Debrecen, Ótemetö utca 2-4., (52) 415 155, \\ ${ }^{1}$ kristof_barnabas1996@yahoo.com \\ ${ }^{2}$ tothjanos@eng.unideb.hu
}

\begin{abstract}
Nowadays, the number of smart homes is increasing steadily. People tend to do anything for better comfort for their family, or simply themselves. We spend roughly half of our lives at home, so It's only logical, to focus, and pursue higher comfort levels for our homes. This phenomenon opens enormous potential for automation, let that may be automatic garage doors, motorized shutters, access control systems, HVAC systems, or anything beyond that to serve our well-being. In this project, I implemented some automation tasks, using a PLC (Programmable Logic Controller). This approach is different from conventional automation, thanks to the ability of the PLC to control everything in a building, thus, condensing three, or even four floors into one central unit.
\end{abstract}

Keywords: PLC, smart home, control, feedback control.

\section{Összefoglalás}

Napjainkban az „okos” épületek száma egyre jobban gyarapszik. Az ember mindent megtesz a maga, s családja kényelméért. Az emberek nagyjából életük felét otthonaikban töltik, így teljesen érthető, logikus az az igény, hogy az minél kényelmesebb és komfortosabb legyen. Ez viszont az automatizálásnak nyit nagy teret. Automatizált garázskapuk, automatizál redőnyök, beléptető rendszerek, világítás, hütés-fütés és még megannyi kényelmünket szolgáló dolog. A projektben jó pár automatizálási feladatot oldottam meg egy PLC-vel (Programmable Logic Controller). Ez a megoldás eltérő a meglévő automatizált épületekétől abban, hogy egy vezérlő irányít mindent. Egy nagy épület automatizálásához 3, akár 4 szint is lehet a vezérlésben. A legalsó a DDC (Direct Digital Control) amelyek kommunikálnak egymással is.

Kulcsszavak: PLC, okos otthon, irányítás, szabályzás.

\section{Nyomógombok felhasználása}

A PLC négy nyomógombbal rendelkezik (Z1, Z2, Z3 és Z4). Ezekkel a nyomógombok felhasználásával 7 vezérlési feladatot kellett ellátni. A 2. ábra jól szemlélteti a működési elvet. A képen a kitöltött négy- szögek a benyomott állapotát jelzik a gomboknak, míg a kitöltetlen négyszög az alaphelyzetére utal, amikor is nincs benyomva. A Z3-as nyomógomb önmagában nem indít el semmilyen folyamatot. A Z3-as nyomógomb megnyomása vagy épp elengedése a többi nyomógombra van hatással. Müködése hasonlít a SHIFT nyomógomb müködé- 
sére. Mivel a Z3-as nyomógomb kombinációja nem volt elegendő, így kellett még egyet találni. Az utolsó kombináció a Z3, Z2 és Z1. A megnyomás sorrendjére az vonatkozik, hogy elöször mindig a Z3-at kell lenyomni, aztán következhet a többi, azok sorrendje már lényegtelen. Amíg a Z3 és Z1 kombináció a beállított hőmérséklet értékét növeli eggyel, addig a Z3 és Z2 kombináció ugyanezt az értékét csökkenti eggyel. Így nagyon rövid ideig módosítunk egy jelet, de mivel hőmérsékletről van szó, ami lassú lefolyású, így semmi lényegeset nem változtatunk.

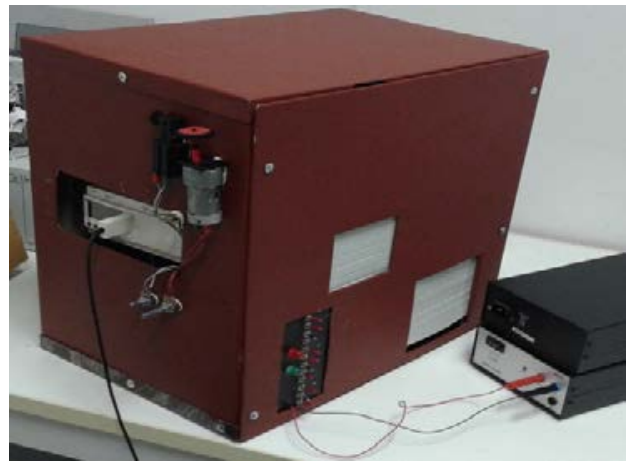

1. ábra. Modellezett okos otthon

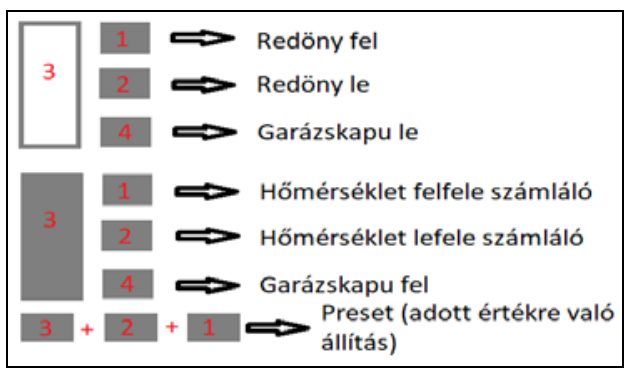

2. ábra. Nyomógombok felhasználása

\section{Redőny irányítás}

Két nyomógomb segítségével vezérelhető a szerkezet. Akármelyik irányba való müködtetésekor, csak addig szabad mozgást végezzen a redőny amíg a nyomógomb le van nyomva vagy épp egy véghelyzetet nem ért el. Így a redőny a „FEL gomb” megnyomására emelkedik, míg a „LE gomb” megnyomására pedig süllyed. A motor csak addig emeli/süllyeszti a redönyszerkezetet, amíg a FEL/LE gomb meg van nyomva. Ez azt biztosítja, hogy bármilyen helyzetében meg lehet állítani a redönyszerkezetet. A feladat részét képezi az is, hogy amikor elért véghelyzetbe, de a kezelő az irányító gombot nem engedték el, akkor a motor múködése leálljon. Ha ez nem így lenne, akkor a szerkezetben valami tönkre mehet. A fel-lemozgatást egy motor végzi, ami azt vetíti elöre, hogy $\mathrm{H}$ híd került beépítésre, a forgásirány váltás megvalósításához. A H híd relés. A $\mathrm{H}$ híd fizikailag nem tartalmazott kizáró vagy feltételt, azaz a megtervezett áramkörbe nem voltak be építve az NC (Normally close) érintkezők. Ahhoz, hogy mégse lehessen rövidre zárni az áramkört a programba lett beágyazva a feltétel. Az általunk megalkotott modellünkben egyik legfontosabb dolog az, hogy felhasználóbarát legyen. Így bárki számára könnyen kezelhető bármelyik része a programnak. Ehhez olyan programkódot írtunk, hogy bármilyen mozgást, változást a kezelő nyomon tudjon követni. [1]

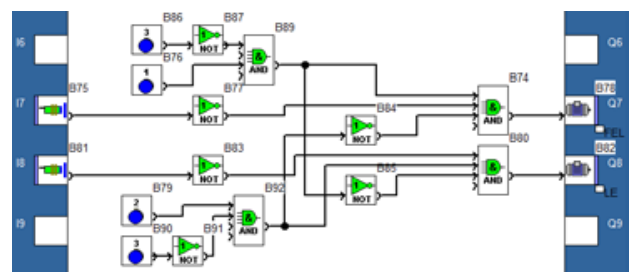

3. ábra. Redőny irányítás programja

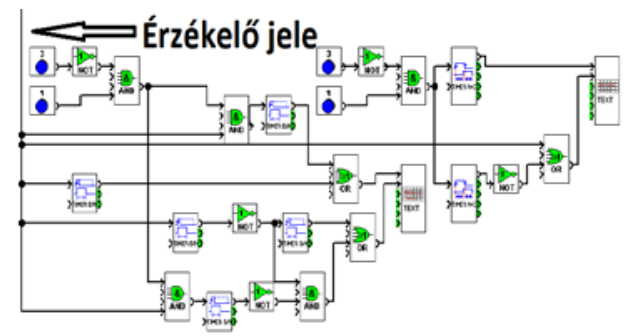

4. ábra. Redöny állapotjelzö programja 


\section{Garázskapu irányítása}

Két nyomógombbal müködtetjük. A nyomógombok megnyomása után csak két véghelyzetben áll meg a kapu. A feladat részét képezi az is, hogy amikor elért véghelyzetbe, de a gombot nem engedték el, akkor a motor müködése leálljon. Ha ez nem így van, akkor a szerkezetben valami tönkre mehet. Ezen felül egy fénysorompó van beépítve, ami nem engedi, hogy a kapu egy gyerekre, kocsira vagy a kapu útjába kerülö bármilyen dologra rázáródjon. Amikor a fénysorompó elé kerül valami akkor az elektromos jelet szolgáltat, ami megfordítja a motor forgásirányát és így az éppen záródó kapu kinyit, ezzel elkerülve a balesetet. A fel-le mozgatást egy elektromotor végzi H híd relés kizáró vagy feltétellel. [2]

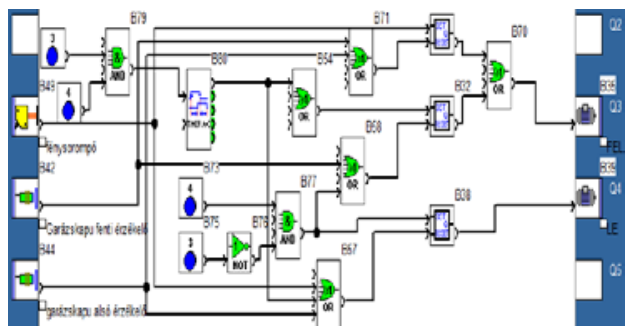

5. ábra: Garázs FBD programja

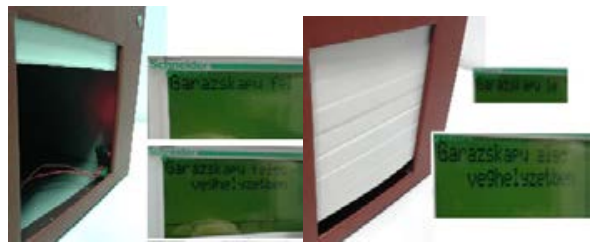

6. ábra. Garázskapu irányítási állapotai

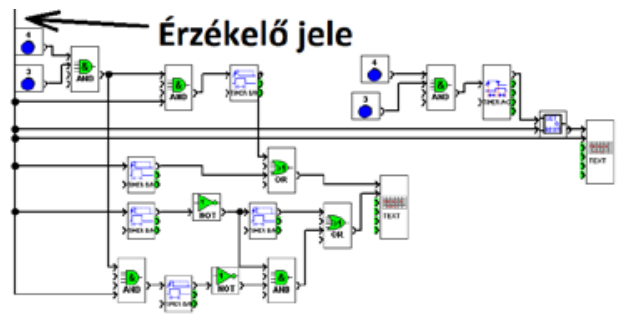

7. ábra. Garázs állapotjelzö programja

\section{Beléptető rendszer}

A megvalósításra váró feladat az volt, hogy a létrehozott beléptető rendszer kódja egy bitsor legyen. Minél hosszabb egy bitsor annál több variációt eredményez. A bekötött mechanikus kapcsolók feleltek meg a biteknek. Mivel nem rendelkeztem nagyon sok bemenettel (a programban mindössze 5 kapcsolót kötöttem be a kapcsolósorból), így „fake”, álkapcsolókat is használtam, ami azt a célt szolgálja, hogy szinte ugyanúgy növeli a lehetséges variációkat, mint a bekötött kapcsolók. Ez azért van így, mivel egy külső szemlélő nem tudja azt, hogy a kapcsolósorból melyik kapcsolónak a jele szolgáltat információt a vezérlőnek vagy éppen melyik nem. Ezzel kiküszöböltük azt a problémát, hogy túl könnyü legyen belépő „kódot” feltörni. Amint az 8. ábrán is fel van tüntetve, a programomban 5 kapcsolót használtam fel (amelyeken nincs piros megkülönböztető müanyag) a tizenkettőből, ezek jelentik a kódot a belépéshez. Ahhoz, hogy ne legyen könnyen feltörhetö a csak logikai 1-est tartalmazó bitsort ki kell zárni a lehetőségek közül, ami eredményezi azt, hogy logikai szinteket negálni kell a programban.

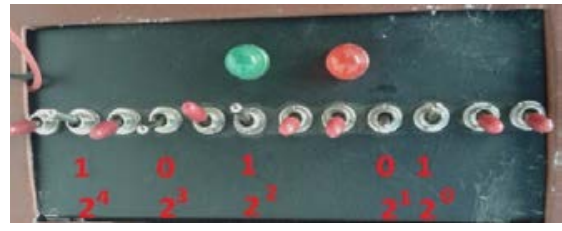

8. ábra. Beléptetö rendszer kódsor

A negált lábak jelentik majd a logikai 0 jelet, így azok átváltásakor így rossz lesz a kódsor. Amennyiben alaphelyzetben maradnak, logikai 0 -át szolgáltatva a vezérlőnek és a másik 3 kapcsolót $\left(2^{\wedge} 4,2^{\wedge} 2,2^{\wedge} 0\right)$ átkapcsoljuk, akkor az elektromágnes, ami addig zárva tartotta az ajtót elenged. Ahhoz, hogy az ajtó ne maradjon nyitva abban az esetben sem, hogyha a kapcsolósor nem kerül alaphelyzetbe, időzítöt állítottam be, 
ami mindössze pár másodpercig tarja nyitva csak az ajtót. Az idő letelte után újra zár az elektromágnes.

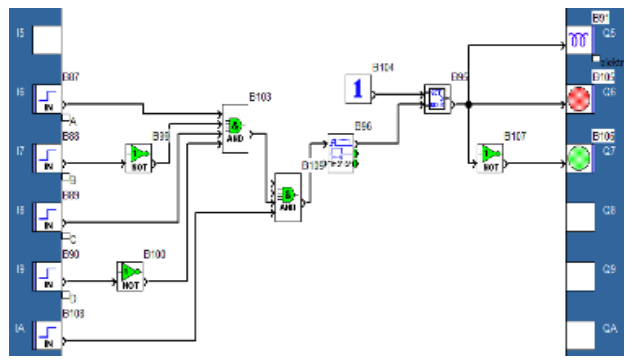

9. ábra. Beléptetö rendszer FBD programja

A Hütés-Fütés a belső hőmérséklet mérése alapján működik. A belső hőmérsékletet hasonlítja össze a felhasználó által beállított, „kívánt” értékkel, ami természetesen bármikor változtatható. Kellett egy átlagos hőmérsékleti érték, amit egy gombnyomásra fel/le lehet állítani. Ez az értéket $20{ }^{\circ} \mathrm{C}$ lett és a PRESET gombbal (ID bemenet) lehet visszaállítani bármikor. Az IB bemenet az UP counter (felfele számláló), míg az IC a DOWN counter (lefele számláló). A felfele- és lefele számlálóval egyszeri megnyomás esetén, egy fokot lehet a kívánt értéken változtatni. A fütésre az igaz, hogy addig kell bekapcsolva legyen, míg a beállított értéknél nagyobb nem lesz a kívánt hőmérséklet, a hütésre pedig épp az ellenkezője.

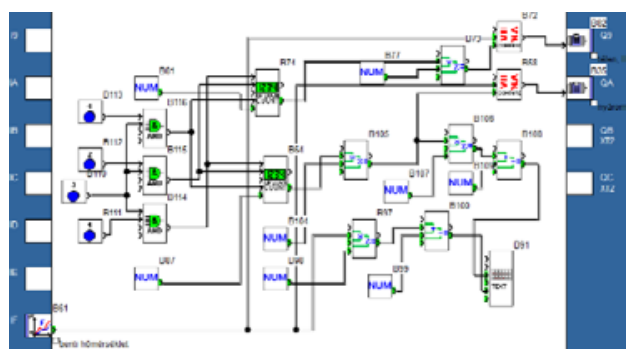

10. ábra. Hütés-Fütés $F B D$ programja

Ahhoz, hogy felhasználóbarát legyen a PLC kijelzőjére ki van írva a beállított- és pillanatnyi, ,jelenlegi” hőmérséklet.

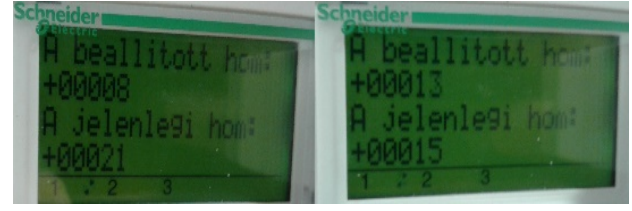

11. ábra. A hömérsékleti beállitása

\section{Konklúzió}

Végkövetkeztetésképp elmondhatjuk, hogy sikerült egy PLC-vel, kevés bemenetikimeneti egység ellenére, nem költséges anyagi beruházásokkal megépíteni egy olyan automatizált modell házat, amelyben komfortosabban élhetünk az automatizált rendszerek nyújtotta „szolgáltatás” miatt.

\section{További fejlesztési törekvések}

Elsősorban minél több automatizálási feladat ellátása a cél, egy háztartáson belül, és persze az energia-hatékony szabályozás megvalósítása. Sok esetben az épületgépész rendszerek jó szabályzása energia megtakarítást eredményez. Mindenképpen egy olyan rendszert kell megvalósítani, amivel az egyedi rendszerek központilag irányíthatóvá tehetők. Ezzel lehet biztosítani az új elvárásokat, mellyel az épületek magasfokú automatizálásával komfortosabb, hatékonyabb rendszerek valósíthatók meg. AZ IoT (Internet of Things) elv terjedésével ez lassan az ipar, a gyártás minden területén elvárás lesz a hatékonyság fokozása céljából. [3]

\section{Szakirodalmi hivatkozások}

[1 Balázs László: Automatika. Müszaki könyvkiadó, Budapest, 2005, 113-133.

[2] Chiara Stein: Selbst intelligente Steuerungstechnik im Haus installieren Compact Praxis - Do It Yourself. Compact Verlag GmbH, München, 2001, 74-83

[3] Szerk.: Kalmár Ferenc: Fenntartható energetika megújuló energiaforrások optimalizált integrálásával. Akadémiai kiadó, Budapest, 2014, 119-143. 